DOI:http://dx.doi.org/10.24093/awejtls/vol1no2.13

\title{
Fictional Characters Outside Fiction: "Being" as a Fictional Character in Heidegger's Being and Time
}

\author{
Abdel-Fattah M. Adel \\ Department of English, College of Science and Arts \\ University of Bisha, Saudi Arabia
}

\begin{abstract}
Can non-fiction present fictional characters? This is the main question of this paper. In reading Martin Heidegger's Being and Time (1927), the readers construct a figure in their mind of a persona about whom all the philosophical reflections are discussed. Heidegger presents Dasein as a 'particular being' that characterizes all the features of human existence. Heidegger did not want to define and explain 'being', but he aimed at presenting a 'sense of being' in the form of characterizing the philosophical reflections he was presenting. After discussing how it can be claimed that Dasein can be considered a 'fictional character' in the absence of a 'plot,' the present article explains the main aspects through which a 'fictional character' is constructed, or figured out, in readers' mind. It tries, also, to show how and why Heidegger resorts to this technique of fictional characterization in this highly influential philosophical book. The article specifies four main personality models, that help construct Dasein as a 'fictional character' in the reader's mind. These personality models are: being-in-world, being-in-time, living-by-activity, and living-to-an-end. By ascribing such personality models to Dasein, Heidegger managed to present in his work a character that can be easily remembered all the time Being and Time is mentioned.
\end{abstract}

Key Words: being, character, characterization, fiction, Heidegger

Cite as: Adel,A.M. (2017). Fictional Characters Outside Fiction: "Being" as a Fictional Character in Heidegger's Being and Time. Arab World English Journal for Translation \& Literary Studies, 1(2). DOI:http://dx.doi.org/10.24093/awejtls/vol1no2.13 